\title{
Geochemical evaluation of the carbonaceous shale of the upper cretaceous Anambra Basin for potential gas generation, Nigeria
}

\author{
George Oluwole Akintola ${ }^{1}$. Phillips Reuben Ikhane ${ }^{2}$ - Francis Amponsah-Dacosta ${ }^{1}$ - Ayoade Festus Adeagbo ${ }^{3}$. \\ Sphiwe Emmanuel Mhlongo ${ }^{1}$ - Joshua Nosa Edokpayi ${ }^{4}$. Vincent Olajide Oladipo ${ }^{2}$. Ademola Oluborode Jegede ${ }^{5}$. \\ Akintunde Isaac Akintola ${ }^{6} \cdot$ Niyiola Olaonipekun Adebisi $^{2}$
}

Received: 29 March 2020 / Accepted: 22 February 2021 / Published online: 8 March 2021

(C) The Author(s) 2021

\begin{abstract}
The rise in demand for natural gas has spurred the need to investigate the inland sedimentary basin for more potential sources. In response, the petrophysical parameters of the carbonaceous shale samples from two deep boreholes of Anambra Basin were evaluated. The gas-prone nature of Nkporo shale showed a thermal evolution of a Type III kerogen with initial HI value between 650 and $800 \mathrm{mgHC} / \mathrm{gTOC}, \mathrm{S} 2 / \mathrm{S} 3<1$, a maximum $T_{\max }$ value of $488^{\circ} \mathrm{C}$ and have a low hydrocarbon generation potential ranging from 0.07 to 0.15 . However, the average TOC content $(2.21 \mathrm{wt} \%)$ indicated a good source rocks for hydrocarbon since it exceeds threshold limit of $0.5 \%$. The plot of HI against $T_{\max }$ shows that the organic matter belongs to the Type-III kerogen which reflects the capability of the Npkoro Formation to generate more natural gas than oil compared to Type-II kerogen. The high values $(>3)$ of pristane/phytane ratio in both wells indicated that the organic matter belongs to terrigenous source deposited under anoxic condition which is typical of non-marine shale. The presence of Oleanane content in the Cretaceous shale sediments indicated the contribution of cell wall and woody plant tissues from the terrestrial higher plant. The low concentrations of extractable organic matter (EOM) present in form of isoprenoid and aliphatic hydrocarbon indicated little or no bitumen extract from the studied shale. Considering the high carbon preference indices (CPI) value greater than 1, the preponderance of vitrinite organic macerals and other favourable aforementioned petrophysical parameters, the non-marine Npkoro Shale Basin has significant potential to generate and expel natural gas apart from the current marine basins.
\end{abstract}

Keywords Natural gas $\cdot$ Upper Cretaceous Shale $\cdot$ Anambra Basin $\cdot$ Type III kerogen · Total organic carbon (TOC)

Responsible Editor: Santanu Banerjee

George Oluwole Akintola

georgeakintola540@gmail.com

1 Department of Mining and Environmental Geology, School of Environmental Sciences, University of Venda, Thohoyandou 0950, Limpopo Province, South Africa

2 Department of Earth Sciences, Faculty of Science, Olabisi Onabanjo University, Ago Iwoye, Nigeria

3 Department of Geology, Faculty of Science, Polytechnic, Ibadan, Nigeria

4 Department of Hydrology and Water Resources, School of Environmental Sciences, University of Venda, Thohoyandou 0950, Limpopo Province, South Africa

5 School of Law, University of Venda, Thohoyandou 0950, Limpopo Province, South Africa

6 Chemoil Energy, 1609 West Florida Avenue, Midland, TX 79701, USA

\section{Introduction}

Natural gas is considered the transitional energy to buffer the negative effect of an abrupt change from crude oil or coal to eco-friendly energy sources. There is a universal understanding that the transition to greener economy should allow inclusive and sustainable economic growth, employment and decent work for the public (Kelman 2017,Unfcc 2015). In sequel to the Paris Agreement 2015, the need to achieve a net zero carbon dioxide $\left(\mathrm{CO}_{2}\right)$ emissions and stabilise global temperatures below $2^{\circ} \mathrm{C}$ is heightened. Consequently, many countries understand an increased role for natural gas in their energy mix considering the reality that electricity produced with gas has half the carbon dioxide emissions of coal power plants (Rui et al. 2017). Natural gas from shale is coming into existence and beginning to display signs of future potential for energy generation. In contrast to conventional gas reservoir, shale gas is marked by self-generation and self-storage 
mechanism because it does not migrate nor diffuse over a long distance due to extremely low permeability of the shale (Chen et al. 2019,Nolte et al. 2019). The enhancement mechanism such as horizontal well-drilling and hydraulic fracturing technologies is recently use to extract natural gas impregnated in an impermeable organic-rich shale rock (Geel et al. 2013,Wang et al. 2018, Thomas et al. 2017). The successful and commercial application of these techniques for shale gas production in the USA and other countries such as Canada and China has spurred interests to searching for natural gas deposits in porous but impermeable organic-rich shale formations (Xi et al. 2018). By implication, countries which heavily depend on coal or crude oil resources to generate their electricity and power consumption are constrained to increase their gas production or importation. As such, the renaissance of natural gas-rich resource is crucial to significantly expand the current global energy landscape.

In past decades, the Niger Delta Basin has been considered the only prolific oil and gas-bearing field in Nigeria until the humongous demand for natural gas necessitated further investigation (Giwa et al. 2019, Giwa et al. 2014,Ojijiagwo et al. 2018). Thus, searching for natural gas formation in the adjacent Anambra Basin was aimed to complement the current production from the Niger Delta Basin. The Anambra Basin is a synclinal structure composed of Cretaceous to younger sediments attaining a thickness of about $6 \mathrm{~km}$ (Adebayo et al. 2018,Akande et al. 2015,Edwards and Santogrossi 1990). The basal sedimentary facies of the Anambra Basin include the Nkporo shale and corresponding equivalent of the Enugu and Owelli Sandstones but deposited by alternating marine transgression about 84 million years ago during the Campanian period. Overlying the Nkporo shale is the lower coal- rich Mamu Formation which is made up of clay shales, carbonceous shale sandy shale and coal seams. The tectonic subsidence during Maastrichtian resulted in regression movement and subsequent deposition of swamp tidal flats which formed the lower coal measure. Following the Mamu Formation is the poorly sorted but medium to coarse grained facies of Ajali sandstone. The Ajali sandstone formation consists of coarse sandstones, lenticular shales, beds of grits and pebbles. This formation exhibits varied age spanning from middle to late Maastrichtian from place to place due to alternating transgressive and regressive movement related to the tectonic inversion ensued from the Santonian compression. This formation is sequentially overlain by the successive sedimentary formation the Nsukka, Imo, Ameki and OgwashiAsaba Formations.

In the Anambra Basin, some retrospective study have indicated the progressive maturity of organic matter to range from 0.55 to $4.31 \%$ using vitrinite reflectance, illite crystallinity and fluid inclusion techniques (Akande et al. 2005,Akande and Erdtmann 1998). Whilst this ranged seems to correspond to the Maastrichian to Albian shales, the Anambra basin had been suggested to be terrestrially provenanced contrary to previous interpretations of marine pro-delta. Recent studies revealed its petroliferous nature (Obaje et al. 2004,Akande et al. 2015,Anakwuba et al. 2018) but not exhaustive in terms of formations that composed the basin. To resolve the gap, this study aims at evaluating the petrophysical parameters of the Npkoro shale samples for natural gas generation.

\section{Geological setting}

The Anambra Basin is a NE-SW trending syncline belonging to African Rift System which developed in response to the stretching and subsidence of major crustal blocks during a Lower Cretaceous break-up phase of the Gondwana SuperContinent (Ogala 2012, Ogala et al. 2019). The basin covers an area of about $218 \mathrm{~km}^{2}$ and is between the coordinates of $5^{\circ} 54^{\prime}$ $40.89^{\prime \prime}$ to $6^{\circ} 35.09^{\prime \prime}$ North and $7^{\circ} 3^{\prime} 32.46^{\prime \prime}$ to $7^{\circ} 15^{\prime} 32.11^{\prime \prime}$ East ( Fig. 1a). It is characterised with sequence of shales and sandstones which interbedded with coal seams particularly in Nkporo and Nsukka Formations. This basin composed of Cretaceous to younger sediments with the thickness greater than $5000 \mathrm{~m}$ but precede the development of the Tertiary Niger Basin (Adebayo et al. 2018,Akande et al. 2015, Edwards and Santogrossi 1990, Bassey and Eminue 2012). According to Okoyeh et al. (2014), the geologic movement that led to the formation of the Anambra Basin was reactivated by further planet activities in Lower Tertiary soon after the intermittent Upper Cretaceous rifting. Sediments deposition in the basin began during the Campanian with Nkporo shales at the bottom which are sequentially overlain by Mamu, Ajali, Nsukka, Imo, Ameki and Ogwashi-Asaba Formations (Ikhane et al. 2019; Akaegbobi et al. 2000; Onuigbo et al. 2012) as shown in Fig. $1 b$.

\section{Materials and methods}

\section{Collection of samples}

A total of eighteen deep core shale samples belonging to two different boreholes of Nkporo Formation in the Anambra Basin were studied. The borehole samples, which were provided by the Nigeria Geological Survey Agency, are selected because they represent the studied formation at varied depths from $1522 \mathrm{~m}$ to $1900 \mathrm{~m}$ and $3360 \mathrm{~m}$ to $3900 \mathrm{~m}$. The lithologic descriptions of the samples were carried out using a magnifying glass to ascertain which portion of the core samples to subject to further analyses. These analyses include the determination of major and trace element composition of the shale samples, determination of total organic contents (TOC), 


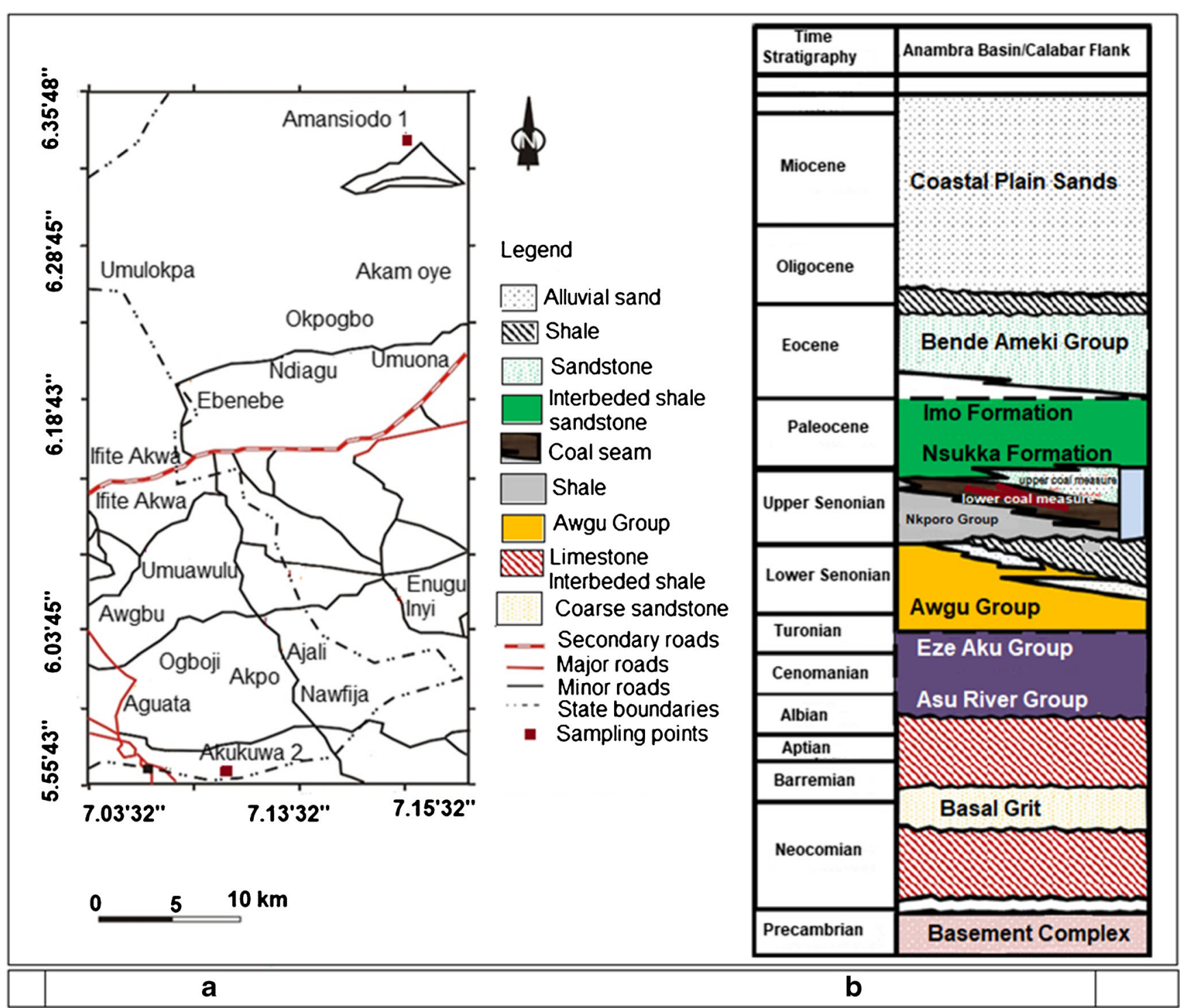

Fig. 1 a Location of the borehole shale samples and $\mathbf{b}$ regional stratigraphy of the Anambra Basin (modified after Bassey and Eminue 2012)

Rock-Eval 6 pyrolysis, extraction of soluble organic matter, biomarker analysis and maceral analysis.

\section{Geochemical analysis}

The geochemical analysis of major and trace elements for the studied shale sample was performed using inductively coupled plasma-1000 spectrometer. The pulverised shale samples $(\sim 0.5 \mathrm{~g})$ were place in conical bottles upon which $5 \mathrm{~g}$ of ammonium sulphate and $10 \mathrm{~mL}$ of sulphuric acid were added at $50^{\circ} \mathrm{C}$ for $12 \mathrm{~h}$. Afterwards, distilled water was added to dilute the mixture until $100 \mathrm{~mL}$ volumetric flask was filled. The spectral intensities of the mixture were measured at various wavelength using the spectrometer whilst the data set were processed using the wavelet transform. The detection limit is $0.01 \%$ for major and trace elements.

\section{Rock-Eval pyrolysis and total organic carbon analyses}

The hydrocarbon potential and the thermal maturity of the kerogen occurring in the studied shale samples were evaluated using a Rock-Eval 6 pyrolyzer. Twenty-five grams of shale samples were pulverized using Fa-Siebtechnik grinding machine for $10 \mathrm{~min}$ and subsequently pyrolyzed in an inert atmosphere of nitrogen. The pyrolysis which was controlled with flame ionisation detector (FID) releases hydrocarbon $S_{1}$ and $S_{2}$ between $300^{\circ} \mathrm{C}$ and $750^{\circ} \mathrm{C}$ at the rate of $25^{\circ} \mathrm{C} / \mathrm{min}$. Whilst the $S_{1}$ is designated as free hydrocarbon, the $S_{2}$ is the hydrocarbon released with further thermal cracking. The detected gases, $\mathrm{CO}$ and $\mathrm{CO}_{2}$, and the remaining carbon residual are designated $S_{3}$ and $S_{4}$ respectively whilst $T_{\max }$ represents the temperature at which hydrocarbon generation is maximum. Important parameters such as hydrogen and oxygen indices which were not measured directly are calculated as a 
weight percentage using 1, 2 and 3 consequently.

$$
\begin{aligned}
& \mathrm{HI}=S_{2} / \text { TOC }_{\text {pyro }} \times 100 \\
& \mathrm{PI}=S_{1} /\left(S_{1}+S_{2}\right) \\
& \mathrm{OI}=S_{3} / \mathrm{TOC}_{\text {pyro }} \times 100 \\
& \mathrm{TOC}_{\text {pyro }}=\left[0.082\left(S_{1}+S_{2}\right)+S_{4}\right] / 10
\end{aligned}
$$

The determination of total organic carbon (TOC) of the shale rock is crucial because it provides information about the hydrocarbon type, quality and potential generation of the shale formation. Shale rock with TOC value $\geq 0.50 \%$ is regarded as an indicator of a good quality source rocks (Al-Selwi and Joshi 2015). The core samples of shale rock are collected and crushed into smaller sizes after which $500 \mathrm{~g}$ is weighed and pulverized to finely ground sizes $<500 \mu \mathrm{m}$ using a mechanical crusher. Then, $20 \mathrm{~g}$ of the fine shale groundmass is mixed with $2 \mathrm{~N}$ of $\mathrm{HCl}$ acid to removed inorganic carbon that might present from sources such as calcite, dolomite and siderite minerals. The sample is then placed in the sealed tube combustor with a temperature at $900^{\circ} \mathrm{C}$ to ensure complete combustion of the sample in an oxygen environment. The oxygen tank is regulated at a constant pressure of $200 \mathrm{psi}$ and the gas carrier at $150 \mathrm{ml} / \mathrm{min}$. As the combustor operates, the inorganic carbon (IC) is converted to $\mathrm{CO}_{2}$ and removed from the IC furnace which is kept at temperature of about $200^{\circ} \mathrm{C}$. The TOC is obtained by measuring the TC using SSM-TC in weight percent.

\section{Organic maceral analysis}

Identification of maceral composition of the dispersed organic matter, DOM, in shale samples from the two studied boreholes was examined following the ASTM D7708-14 standard procedure. This procedure is based on the separation of the organic macerals and measuring its vitrinite reflectance in oil immersion lens using a reflecting polarising microscope connected with a photometer. Prior to determining the reflectance, the microscope linearity is calibrated using predetermined glass index of $546 \mathrm{~nm}$ and precautions are taken into considerations. The precautions include avoiding a scratch-free polished vitrinite grain, periodic calibration of standard during actual measurement and accurate selection of proper objective and measuring diaphragm. Based on the available organic matter, more than 25 vitrinite grain is measured using a Zeiss Axio Imager M2, retrofitted with Hilgers Fossils Diskus system by rotating the stage up to $360^{\circ} \mathrm{C}$ to avoid suppression of vitrinite grains and then recorded.

\section{Biomarker compositional analyses}

The biomarker components which provide information on the source of organic matter, the environment of deposition and thermal maturity of studied shale samples were examined using gas chromatography-mass spectroscopy (GC-MS). Three millilitres each of hexane $\left(\mathrm{C}_{6} \mathrm{H}_{14}\right)$, dichloromethane $\left(\mathrm{Ch}_{2} \mathrm{Cl}_{2}\right)$ and methanol $\left(\mathrm{Ch}_{3} \mathrm{OH}\right)$ was used to elute organic matter (EOM) in the column into separate extractable aliphatic, aromatic and polar fractions. Unlike the polar fractions which are mainly composed of nitrogen, sulphur and oxygen compounds, the aliphatic and aromatic fractions showed less complexity in further reactions with dissolved hexane and dichloromethane respectively. The mass spectrum of the aliphatic and aromatic fractions was detected with the mass spectrometer detector imbued with helium gas. Mass spectrum peaks of the fractions were identified by comparing the retention time and extractable order with a known mass spectral database of NIST08.

\section{Results and discussion}

\section{Geochemical characterisation}

\section{Major elemental composition}

Major oxides of forty (40) shale samples from depth $1440 \mathrm{~m}$ to $1906 \mathrm{~m}$ in well 1 and depth $3297 \mathrm{~m}$ to $3850 \mathrm{~m}$ in well 2 are presented in Table 1. In well 1, the average percentage of $\mathrm{SiO}_{2}$ (56.40\%), $\mathrm{Al}_{2} \mathrm{O}_{3}(29.27 \%), \mathrm{TiO}_{2}(0.84 \%), \mathrm{K}_{2} \mathrm{O}(0.94 \%)$, $\mathrm{Na}_{2} \mathrm{O}(0.85 \%), \mathrm{MgO}(4.70 \%), \mathrm{CaO}(1.65 \%), \mathrm{Fe}_{2} \mathrm{O}_{3}(5.22 \%)$ and $\mathrm{MnO}(0.15 \%)$ is similar to the elemental values obtained in well 2 despite the different borehole points and elevations. This similarity could be attributed to the repeated facies of lithologies in the Anambra synclinal basin. According to the geochemical proxy plot of $\mathrm{TiO}_{2}$ and $\mathrm{Ni}$ (Fig. 2a), both wells plot in the domain of magmatogenetic and greywackes origin. This domain explains argillaceous nature of the shale and the high content of $\mathrm{SiO}_{2}$ suggested that the source rocks of the shales in the study area were felsic igneous rocks. Due to the immobility nature of oxides of $\mathrm{Al}$ and Ti elements, the ratio of $\mathrm{Al}_{2} \mathrm{O}_{3} / \mathrm{TiO}_{2}$ values of shale sample suggests the felsic character of the source rocks (Fig. 2b). The oxides of $\mathrm{Al}$ and Ti elements form a robust technique to interpret residual sediments due to their immobile nature during fluvial transport of weathered rocks(Hayashi et al. 1997,Mclennan et al. 1980). Furthermore, on the $\mathrm{Al}_{2} \mathrm{O}_{3}-$ $\left(\mathrm{CaO}+\mathrm{Na}_{2} \mathrm{O}+\mathrm{K}_{2} \mathrm{O}\right)-\left(\mathrm{Fe}_{2} \mathrm{O}+\mathrm{MgO}\right)$ ternary diagram presented in Fig. 3, the studied shale samples plot away from $\left(\mathrm{Fe}_{2} \mathrm{O}+\mathrm{MgO}\right)$ apex and trend towards $\mathrm{Al}_{2} \mathrm{O}_{3}$ apex. The plots of the shale samples on this AFM diagram are consistent with the felsic nature attributed to the source rocks. It implies that the geochemical variation of the well 1 and 2 depicts terrigenous source.

The Index of Compositional Variation (ICV) values showed similar trends in both well 1 and well 2, ranged from 0.416 to 0.516 with average value less than 1 thus suggesting source rock rich in felsic minerals (Cox et al. 1995,Baioumy 
Table1 Major elemental composition of studied shale samples

\begin{tabular}{|c|c|c|c|c|c|c|c|c|c|c|c|}
\hline Well-1 & $\operatorname{Depth}(\mathrm{m})$ & $\mathrm{MnO}_{2}(\%)$ & $\mathrm{Fe}_{2} \mathrm{O}_{3}(\%)$ & $\mathrm{CaO}(\%)$ & $\mathrm{MgO}(\%)$ & $\mathrm{Na}_{2} \mathrm{O}(\%)$ & $\mathrm{K}_{2} \mathrm{O}(\%)$ & $\mathrm{Al}_{2} \mathrm{O}_{3}(\%)$ & $\mathrm{SiO}_{2}(\%)$ & $\mathrm{TiO}_{2}(\%)$ & ICV \\
\hline S-1 & 1440 & 0.14 & 4.95 & 1.65 & 4.52 & 0.84 & 0.90 & 28.63 & 57.0 & 0.84 & 0.454 \\
\hline S-2 & 1476 & 0.14 & 5.12 & 1.75 & 4.04 & 0.82 & 0.98 & 29.02 & 56.7 & 0.84 & 0.443 \\
\hline S-3 & 1522 & 0.14 & 5.10 & 1.70 & 4.68 & 0.85 & 1.00 & 29.30 & 57.0 & 0.88 & 0.460 \\
\hline S-4 & 1530 & 0.14 & 4.84 & 1.68 & 4.84 & 0.86 & 0.98 & 30.10 & 56.8 & 0.86 & 0.443 \\
\hline S-5 & 1542 & 0.15 & 4.86 & 1.64 & 4.64 & 0.88 & 0.99 & 30.02 & 54.4 & 0.89 & 0.438 \\
\hline S-6 & 1575 & 0.14 & 5.05 & 1.68 & 5.20 & 0.90 & 0.96 & 29.26 & 55.6 & 0.85 & 0.476 \\
\hline S-7 & 1691 & 0.23 & 4.99 & 1.70 & 4.70 & 0.82 & 0.94 & 28.55 & 57.8 & 0.85 & 0.469 \\
\hline S-8 & 1.640 & 0.24 & 5.01 & 1.56 & 6.16 & 0.85 & 0.97 & 28.67 & 54.5 & 0.90 & 0.516 \\
\hline S-9 & 1670 & 0.13 & 4.65 & 1.58 & 4.54 & 0.89 & 0.90 & 28.77 & 56.7 & 0.83 & 0.441 \\
\hline S-10 & 1680 & 0.14 & 4.95 & 1.69 & 4.59 & 0.84 & 0.96 & 29.37 & 56.3 & 0.86 & 0.448 \\
\hline S-11 & 1690 & 0.14 & 4.84 & 1.65 & 4.55 & 0.83 & 0.94 & 28.39 & 54.2 & 0.84 & 0.456 \\
\hline $\mathrm{S}-12$ & 1693 & 0.15 & 5.21 & 1.76 & 4.93 & 0.92 & 1.00 & 32.05 & 56.1 & 0.86 & 0.436 \\
\hline S-13 & 1706 & 0.25 & 4.24 & 1.65 & 4.80 & 0.83 & 0.95 & 28.35 & 56.9 & 0.85 & 0.449 \\
\hline S-14 & 1726 & 0.13 & 4.84 & 1.66 & 4.39 & 0.86 & 0.95 & 30.87 & 56.7 & 0.88 & 0.416 \\
\hline S-15 & 1745 & 0.12 & 10.4 & 1.50 & 4.55 & 0.75 & 0.86 & 27.33 & 55.1 & 0.88 & 0.665 \\
\hline S-16 & 1775 & 0.13 & 5.00 & 1.62 & 4.22 & 0.84 & 0.88 & 28.77 & 55.1 & 0.87 & 0.441 \\
\hline S-17 & 1790 & 0.13 & 5.24 & 1.48 & 4.62 & 0.76 & 0.85 & 29.22 & 54.3 & 0.86 & 0.448 \\
\hline S-18 & 1813 & 0.14 & 4.98 & 1.68 & 4.61 & 0.85 & 0.95 & 29.89 & 56.0 & 0.88 & 0.442 \\
\hline S-19 & 1903 & 0.13 & 5.10 & 1.71 & 4.67 & 0.86 & 0.95 & 29.31 & 56.9 & 0.82 & 0.458 \\
\hline S-20 & 1906 & 0.14 & 4.97 & 1.68 & 4.54 & 0.84 & 0.94 & 29.56 & 58.7 & 0.80 & 0.444 \\
\hline Mean & & 0.15 & 5.22 & 1.65 & 4.70 & 0.85 & 0.94 & 29.27 & 56.8 & 0.86 & 0.485 \\
\hline Well-2 & Depth(m) & $\mathrm{MnO}_{2}$ & $\mathrm{Fe}_{2} \mathrm{O}_{3}$ & $\mathrm{CaO}$ & $\mathrm{MgO}$ & $\mathrm{Na}_{2} \mathrm{O}$ & $\mathrm{K}_{2} \mathrm{O}$ & $\mathrm{Al}_{2} \mathrm{O}_{3}$ & $\mathrm{SiO}_{2}$ & $\mathrm{TiO}_{2}$ & ICV \\
\hline S-1 & 3297 & 0.14 & 5.01 & 1.74 & 4.28 & 0.86 & 0.99 & 29.14 & 57.02 & 0.88 & 0.447 \\
\hline S-2 & 3314 & 0.14 & 4.88 & 1.65 & 4.55 & 0.73 & 0.96 & 29.47 & 56.78 & 0.86 & 0.438 \\
\hline $\mathrm{S}-3$ & 3346 & 0.15 & 4.90 & 1.64 & 4.37 & 0.84 & 0.92 & 29.30 & 57.00 & 0.84 & 0.438 \\
\hline S-4 & 3369 & 0.14 & 5.04 & 1.70 & 4.44 & 0.84 & 0.92 & 29.22 & 56.84 & 0.86 & 0.448 \\
\hline S-5 & 3412 & 0.15 & 5.12 & 1.74 & 4.91 & 0.82 & 1.01 & 30.92 & 54.44 & 0.89 & 0.445 \\
\hline S-6 & 3474 & 0.14 & 5.01 & 1.56 & 5.79 & 0.84 & 0.93 & 29.26 & 55.64 & 0.85 & 0.488 \\
\hline S-7 & 3481 & 0.13 & 4.83 & 1.65 & 4.76 & 0.80 & 0.95 & 30.26 & 57.80 & 0.85 & 0.434 \\
\hline S-8 & 3514 & 0.14 & 5.11 & 1.56 & 4.55 & 0.88 & 0.01 & 28.23 & 54.55 & 0.90 & 0.434 \\
\hline S-9 & 3543 & 0.13 & 4.86 & 1.65 & 4.69 & 0.81 & 0.88 & 31.10 & 56.76 & 0.83 & 0.419 \\
\hline S-10 & 3558 & 0.14 & 4.06 & 1.61 & 5.12 & 0.87 & 0.91 & 29.39 & 56.32 & 0.86 & 0.432 \\
\hline S-11 & 3576 & 0.14 & 5.10 & 1.75 & 5.16 & 0.90 & 0.91 & 30.12 & 54.21 & 0.84 & 0.463 \\
\hline S-12 & 3591 & 0.14 & 5.08 & 1.69 & 4.15 & 0.81 & 1.00 & 30.13 & 56.16 & 0.86 & 0.427 \\
\hline S-13 & 3619 & 0.14 & 5.09 & 1.70 & 4.47 & 0.84 & 0.98 & 28.99 & 56.95 & 0.85 & 0.456 \\
\hline S-14 & 3647 & 0.14 & 5.06 & 1.67 & 4.88 & 0.82 & 0.96 & 28.85 & 56.74 & 0.88 & 0.469 \\
\hline S-15 & 3689 & 0.14 & 5.18 & 1.73 & 4.46 & 0.87 & 0.97 & 30.61 & 55.16 & 0.88 & 0.436 \\
\hline S-16 & 3704 & 0.14 & 5.91 & 1.70 & 3.94 & 0.84 & 0.98 & 31.50 & 55.12 & 0.87 & 0.429 \\
\hline S-17 & 3866 & 0.14 & 5.18 & 1.77 & 4.02 & 0.88 & 0.97 & 31.16 & 54.32 & 0.86 & 0,416 \\
\hline S-18 & 3793 & 0.14 & 5.07 & 1.70 & 4.99 & 0.87 & 0.97 & 31.31 & 56.04 & 0.88 & 0.439 \\
\hline S-19 & 3808 & 0.13 & 4.89 & 1.69 & 4.29 & 0.81 & 0.97 & 28.74 & 56.96 & 0.82 & 0.445 \\
\hline S-20 & 3850 & 0.13 & 4.76 & 1.62 & 4.29 & 0.82 & 0.93 & 27.94 & 58.71 & 0.80 & 0.449 \\
\hline Mean & & 0.14 & 5.0 & 1.69 & 4.58 & 0.84 & 0.91 & 29.81 & 56.8 & 0.86 & 0.465 \\
\hline
\end{tabular}

$\mathrm{ICV}=\left(\mathrm{Fe}_{2} \mathrm{O}_{3}+\mathrm{K}_{2} \mathrm{O}+\mathrm{Na}_{2} \mathrm{O}+\mathrm{CaO}+\mathrm{MgO}+\mathrm{MnO}\right) / \mathrm{Al}_{2} \mathrm{O}_{3}$

et al. 2018). The ICV values allude to the $\mathrm{Al}_{2} \mathrm{O}_{3} / \mathrm{TiO}_{2}$ values suggesting felsic origin whilst ICV value greater 1 have been attributed to mafic rock forming minerals such as plagioclase, amphiboles and pyroxene (Baioumy et al. 2018). 


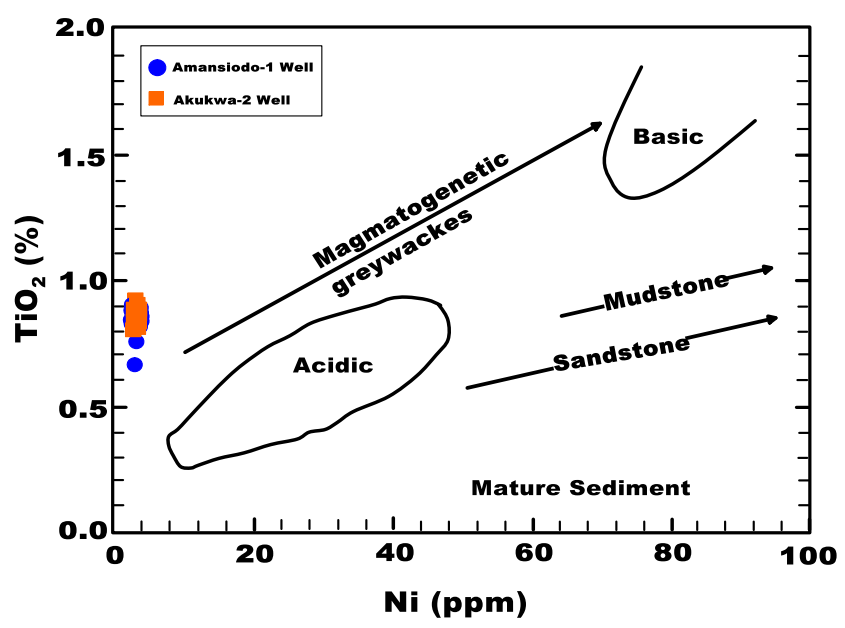

Fig. 2 Provenance indicating diagram $\mathrm{TiO}_{2} \%$ versus $\mathrm{Ni}(\mathrm{ppm})$ bivariate diagram after (Floyd et al. 1991)

The trace element distribution in studied well 1 and 2 reflects the concentration of the proximal and distal depth of the Nkporo shale Formation (Tables 2 and 3). The most abundant biophile element in the studied samples is $\mathrm{Zr}$ with concentration ranging from 11.55 to $10.20 \mathrm{ppm}$ followed by Co and V with average concentration of 0.71 and 0.65 respectively. Although these biophile elements $(\mathrm{Zr}>\mathrm{Co}>\mathrm{V})$ do not show any trend with depth variation, the $\mathrm{V} / \mathrm{Zr}$ ratio above 2 suggests the deposition of the studied samples under anoxic paleo-conditions. The enrichment of $\mathrm{Zr}, \mathrm{V}$ and $\mathrm{Co}$ is immobile and showed sediment recycling of clastic origin under reducing environments. This situation is contrary to the biophile elements of the Orange and Delta Basins which showed abundance in an order of $\mathrm{V}>\mathrm{Ni}>\mathrm{Co}$ with high content of $\mathrm{Fe}$ having an average concentration of 32,200 ppm (Akinlua et al. 2010b). The low Fe content in the studied elements suggests an overmatured sediment where intense reworking processes have taken place during fluvial transportation compared to the Orange and Niger Delta sedimentary basin where Fe is the most abundant in Crude oils and Bitumens (Akinlua et al. 2016,Nwachukwu et al. 2018). It is noted that less Fe oxide is concentrated in organic rich sediments derived from freshwater in contrast to marine equivalents; thus, nonmarine sediments commonly have $\mathrm{V} / \mathrm{Zr}$ value greater than 2(Hofer et al. 2013).

The mixed organic matter basins predominately display a decreasing concentration of elements $\mathrm{Zr}>\mathrm{Co}>\mathrm{V}$ (Akinlua et al. 2010b; Akinlua et al. 2016). The high concentration of $\mathrm{Zr}$ element in the shale samples may significantly indicate a less anoxic environment (Akinlua et al. 2010a). Zr and V have been reported to have significant concentrations in the organic fraction of kerogen and Co is known to be useful as a paleoenvironmental indicator because its concentration increases with increasing anoxic conditions (Jegede et al. 2018; Akinlua et al. 2015; Alberdi-Genolet and Tocco 1999) The trend of trace element distribution in well 1 and 2 suggests similar paleoenvironmental conditions of deposition for the studied shale sediments. The concentration of $\mathrm{Pb}$ and As elements is low, although they have significant importance in terms of environmental pollution and catalytic poisoning of refining columns. In addition, the redox reaction of the depositional environments was deciphered with elemental proxies of $\mathrm{V} /(\mathrm{V}+\mathrm{Ni})$ fractions with value $>0.8$ indicating that the shale sediments were deposited in a reducing condition (Lewan 1984). As such, the high proportion of $\mathrm{V}$ in these samples is a strong indication of oxidising conditions during the deposition of the organic matter (Sundararaman et al. 1993).

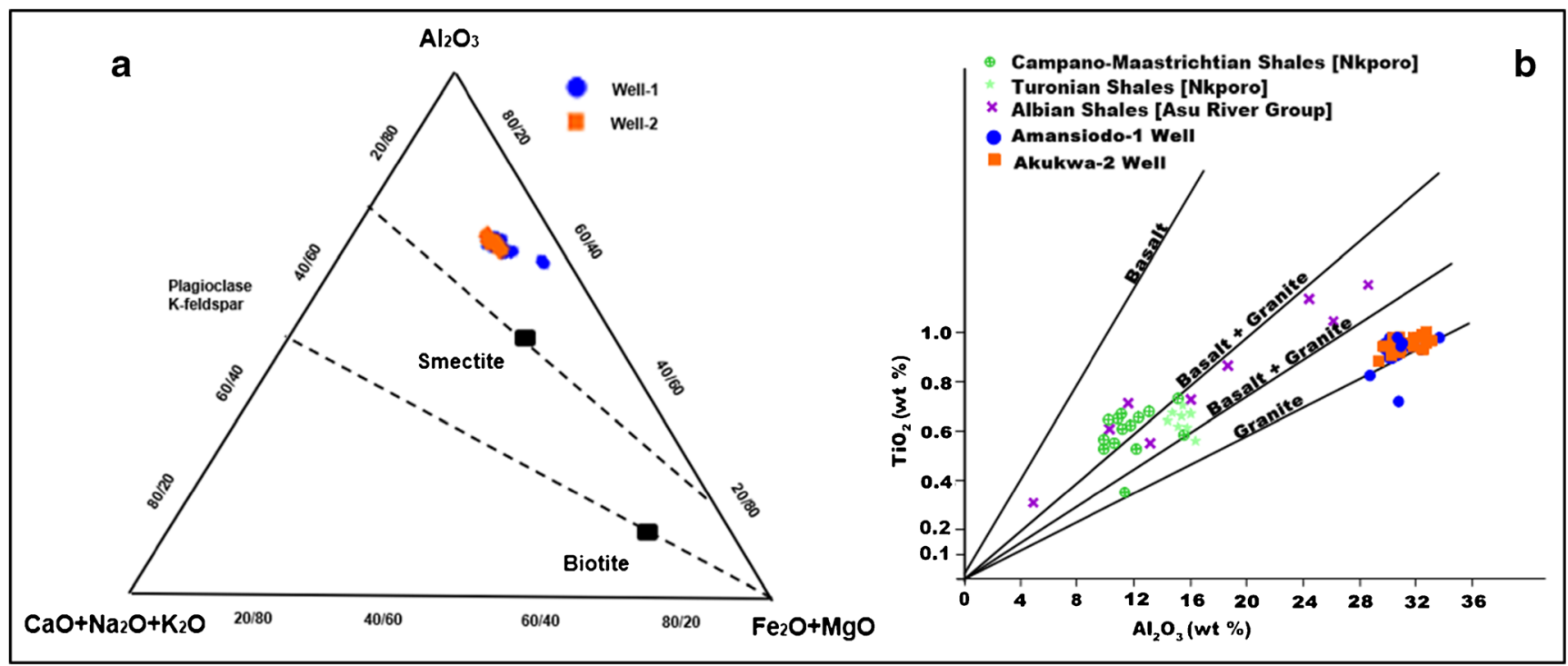

Fig. 3 a Provenance indicating bivariate plot of $\mathrm{Al}_{2} \mathrm{O}_{3}-\left(\mathrm{CaO}+\mathrm{Na}_{2} \mathrm{O}+\mathrm{K}_{2} \mathrm{O}\right)-\left(\mathrm{Fe}_{2} \mathrm{O}_{3}+\mathrm{MgO}\right)$ ternary diagram (after Hayashi et al. 1997). b Provenance indicating bivariate plot of $\mathrm{TiO}_{2} \%$ versus $\mathrm{Al}_{2} \mathrm{O}_{3} \%$ (after Mclennan et al. 1980) 
Table 2 Results of trace elements concentration of well-1

\begin{tabular}{|c|c|c|c|c|c|c|c|c|c|c|c|c|c|c|c|c|}
\hline \multirow{2}{*}{$\begin{array}{l}\text { Well- } \\
1\end{array}$} & \multirow[t]{2}{*}{ Depth (m) } & \multicolumn{10}{|c|}{ Element in ppm } & \multirow[b]{2}{*}{ TTM } & \multirow[b]{2}{*}{$\begin{array}{l}\mathrm{CO} / \\
\mathrm{Ni}\end{array}$} & \multirow[b]{2}{*}{$\mathrm{V} / \mathrm{Ni}$} & \multirow[b]{2}{*}{$\begin{array}{l}\mathrm{Mo} / \\
\mathrm{Ni}\end{array}$} & \multirow[b]{2}{*}{$\begin{array}{l}\mathrm{V} / \\
\mathrm{V}+\mathrm{Ni}\end{array}$} \\
\hline & & $\mathrm{Ni}$ & Co & $\mathrm{Pb}$ & $\mathrm{Be}$ & $\mathrm{Zr}$ & As & $\mathrm{V}$ & $\mathrm{Fe}$ & $\mathrm{Ce}$ & Mo & & & & & \\
\hline S-1 & 1440 & 375 & 0.654 & 0.311 & 0.238 & 10.44 & 118 & 0.635 & 0.038 & 0.584 & 0.27 & 34 & 1.744 & 1.693 & 0.072 & .628 \\
\hline $\mathrm{S}-2$ & 1476 & 0.339 & 0.718 & 0.336 & 0.227 & 10.45 & 0.121 & 0.577 & 0.059 & 0.658 & 0.036 & 1.670 & 2.118 & 1.702 & 1.106 & 0.644 \\
\hline $\mathrm{S}-3$ & 1522 & 0.321 & 0.657 & 0.329 & 0.245 & 10.68 & 0.119 & 0.667 & 0.046 & 0.596 & 0.029 & 1.671 & 2.047 & 2.078 & 0.090 & 0.676 \\
\hline S-4 & 1530 & 0.385 & 0.695 & 0.363 & 0.236 & 10.65 & 0.117 & 0.668 & 0.045 & 0.485 & 0.036 & 1.784 & 1.805 & 1.735 & 0.094 & 0.635 \\
\hline S-5 & 1542 & 0.385 & 0.735 & 0.328 & 0.248 & 10.18 & 0.126 & 0.647 & 0.055 & 0.695 & 0.023 & 1.740 & 1.909 & 1.681 & 0.060 & 0.627 \\
\hline S-6 & 1575 & 0.366 & 0.693 & 0.348 & 0.235 & 10.95 & 0.127 & 0.628 & 0.045 & 0.628 & 0.038 & 1.725 & 1.893 & 1.716 & 0.104 & 0.632 \\
\hline S-7 & 1691 & 0.349 & 0.668 & 0.366 & 0.219 & 11.55 & 0.125 & 0.596 & 0.036 & 0.654 & 0.042 & 1.655 & 1.914 & 1.708 & 0.120 & 0.631 \\
\hline S-8 & 1640 & 0.329 & 0.678 & 0.344 & 0.226 & 11.18 & 0.123 & 0.638 & 0.047 & 0.654 & 0.027 & 1.672 & 2.061 & 1.939 & 0.082 & 0.647 \\
\hline S-9 & 1670 & 0.348 & 0.685 & 0.358 & 0.227 & 11.02 & 0.129 & 0.558 & 0.039 & 0.695 & 0.029 & 1.620 & 1.968 & 1.603 & 0.083 & 0.616 \\
\hline S-10 & 1680 & 0.355 & 0.745 & 0.327 & 0.238 & 11.16 & 0.127 & 0.628 & 0.043 & 0.654 & 0.044 & 1.772 & 2.099 & 1.769 & 0.124 & 0.639 \\
\hline S-11 & 1690 & 0.349 & 0.735 & 0.345 & 0.233 & 11.48 & 0.127 & 0.637 & 0.067 & 0.685 & 0.024 & 1.745 & 2.106 & 1.825 & 0.069 & 0.648 \\
\hline S-12 & 1693 & 0.319 & 0.685 & 0.342 & 0.228 & 11.25 & 0.133 & 0.558 & 0.067 & 0.552 & 0.046 & 1.628 & 2.147 & 1.749 & 0.144 & 0.636 \\
\hline S-13 & 1706 & 0.318 & 0.722 & 0.33 & 0.221 & 10.68 & 0.116 & 0.635 & 0.048 & 0.666 & 0.028 & 1.703 & 2.270 & 1.997 & 0.088 & 0.660 \\
\hline S-14 & 1726 & 0.355 & 0.628 & 3.08 & 0.225 & 10.28 & 0.112 & 0.695 & 0.046 & 0.658 & 0.025 & 1.703 & 1.769 & 1.958 & 0.070 & 0.688 \\
\hline S-15 & 1745 & 0.345 & 0.735 & 0.329 & 0.245 & 10.78 & 0.122 & 0.554 & 0.049 & 0.445 & 0.028 & 1.662 & 2.130 & 1.606 & 0.081 & 0.616 \\
\hline-16 & 1775 & 0.321 & 0.695 & 0.348 & 0.236 & 10.65 & 0.136 & 0.635 & 0.055 & 0.635 & 0.044 & 1.692 & 2.165 & 1.978 & 0.137 & 0.664 \\
\hline-17 & 1790 & 0.362 & 0.725 & 0.324 & 0.224 & 10.49 & 0.113 & 0.633 & 0.035 & 0.697 & 0.034 & 1.754 & 2.003 & 1.749 & 0.094 & 0.638 \\
\hline-18 & 1813 & 0.363 & 0.742 & 0.335 & 0.244 & 11.35 & 0.125 & 0.628 & 0.053 & 0.478 & 0.035 & 1.768 & 2.044 & 1.730 & 0.096 & 0.629 \\
\hline S-19 & 1903 & 0.334 & 0.667 & 0.338 & 0.237 & 10.75 & 0.124 & 0.664 & 0.035 & 0.528 & 0.028 & 1.693 & 1.997 & 1.988 & 0.084 & 0.665 \\
\hline $\mathrm{S}-20$ & 1906 & 0.376 & 0.688 & 0.342 & 0.24 & 11.25 & 0.123 & 0.647 & 0.039 & 0.658 & 0.035 & 1.746 & 1.830 & 1.721 & 0.093 & 0.632 \\
\hline Mean & & 0.349 & 0.698 & 0.472 & 0.234 & 10.86 & 0.123 & 0.626 & 0.047 & 0.014 & 0.014 & 1.717 & 2.00 & 1.79 & 0.145 & 0.643 \\
\hline
\end{tabular}

\section{Rock-Eval pyrolysis and TOC}

The organic matter quality, type and maturity of the shale samples were investigated for the potential generation of hydrocarbon and presented in Table 4. The Rock-Eval pyrolysis yields relevant parameters such as TOC, S2 and HI to describe the source rock potential. The maximum temperature, $T_{\max }$, at which decomposition of kerogen occurs, varies from $425^{\circ} \mathrm{C}$ to $488^{\circ} \mathrm{C}$ in both lower and upper Nkporo shale with average value at $455^{\circ} \mathrm{C}$. The relatively high $T_{\max }$ values indicate that the dissociation of remaining hydrocarbon required to increase temperature to break the $\mathrm{H}-\mathrm{C}$ bonds and activate energy to release the gases. The average total organic carbon content of the lower and upper Nkporo shale samples is $2.4 \mathrm{wt} \%$ and the value indicates an excellent source because TOC value of more than $0.5 \%$ has been regarded as good source rock (AlSelwi and Joshi 2015,Veld et al. 1993). In comparison with the upper member, the high TOC content in the lower Npkoro shale samples is possibly due to different depths of burial. The lower Nkporo shale has an average $\mathrm{HI}$ value of $6.2 \mathrm{mg} \mathrm{HC} / \mathrm{g}$ TOC thus resulting in Type III kerogen at the initial maturity stage. The distribution of the potential source rock showed that the lower Nkporo shale having depth $>3 \mathrm{~km}$ may produce more gas hydrocarbon than shale formation $<1.5 \mathrm{~km}$ deep.

The gas-prone nature of Nkporo shale showed S2/ S3 < 1 whilst the thermal evolution of a type III kerogen with initial HI was found to be 650 and $800 \mathrm{mgHC} / \mathrm{gTOC}$. The OI values in the upper Npkoro shale samples are high (121.95 to $15.68 \mathrm{mgCO}_{2} / \mathrm{gTOC}$ ) compared to the lower shale samples. There is a usual difference due to deposition of terrestrial vegetative and higher plant materials in the upper formation in an anoxic environment compared to shale in lower formation. The hydrocarbon generating potential showed valued $<1$ and ranging from 0.07 to $0.04 \mathrm{mgHC} /$ grock in both lower and upper Nkporo shale. It implies that the hydrocarbon generating potential of the Nkporo shale is low ranging from 0.07 to 0.15 although the organic matter is gas-prone (Tissot 1984). The HI vs $T_{\max }$ plot showed that the organic matter belongs to the Type-III kerogen which reflects the capability of Npkoro Formation to generate more gas than oil compared to Type-II kerogen (Fig. 4). Similarly, the hydrocarbon generative potential diagram (Fig. 5) of S1+S2 against TOC depicts an admixture of dominant Type III and Type IV 
Table 3 Results of trace elements concentration well-2

Well- Depth (m) Element concentration (ppm)

2

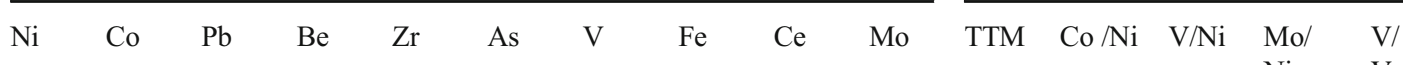

\begin{tabular}{|c|c|c|c|c|c|c|c|c|c|c|c|c|c|c|c|c|}
\hline S- 1 & 297 & 335 & 0.695 & 0.318 & 0.218 & 10.25 & 0.105 & 0.568 & 0.155 & 0.557 & 0.025 & 1.623 & 1.744 & 1.693 & 0.072 & 0.628 \\
\hline-2 & 14 & 319 & 0.654 & 031 & 255 & 3 & 6 & 15 & 68 & 49 & 27 & 15 & 2.18 & 02 & 6 & 0.644 \\
\hline 3 & 3346 & 8 & 0.723 & 0 & 225 & 5 & 0 & 5 & 3 & 8 & 27 & 3 & 7 & 8 & 0 & 0.676 \\
\hline 4 & 3369 & 9 & 0 & 0 & 9 & 11.25 & 0 & 0 & 6 & 8 & 4 & 6 & 1.805 & 5 & 4 & 0.635 \\
\hline-5 & 3412 & 0.355 & 0.734 & 0 & 36 & 2 & 0 & 3 & 0 & 0 & 3 & 3 & 1 & 1 & 0 & 527 \\
\hline-6 & 3474 & 5 & 0.66 & 0 & 246 & 5 & 0 & 0.635 & 0 & 6 & 6 & 1 & 1 & 6 & 4 & 32 \\
\hline 7 & 3481 & 63 & 0.657 & 0.317 & .225 & 3 & 0.124 & 0.625 & 0. & 0.448 & 5 & 0 & 1. & 88 & 20 & 631 \\
\hline-8 & 351 & 345 & 0.66 & 0.3 & .246 & 10. & 0 & 0.6 & 0. & 6 & 6 & 1. & 2 & $y$ & 32 & 547 \\
\hline-9 & 3543 & 0.359 & 0.684 & 0.329 & 0.218 & 10.78 & 0.127 & 0.596 & 0.048 & 0.485 & 0. & 1.6 & 1. & 3 & 0 . & 0 \\
\hline 10 & 3558 & 0.362 & 0.73 & 0.355 & 0.233 & 11.28 & 0.133 & 0.588 & 0.062 & 0.447 & 0.048 & 8 & 2. & 69 & 4 & 0.639 \\
\hline-11 & 3576 & 0.322 & 0.742 & 0.337 & 0.239 & 11.15 & 0.125 & 0.618 & 0.035 & 0.536 & 0.039 & 1.721 & 2.106 & 1.825 & 0.069 & 0.648 \\
\hline-12 & 3591 & 0.328 & 0.688 & 0.363 & 0.245 & 10.45 & 0.124 & 0.635 & 0.053 & 0.557 & 0.023 & 1.674 & 2.147 & 1.749 & 0.144 & 0.636 \\
\hline-13 & 3619 & 0.335 & 0.695 & 0.312 & 0.229 & 10.25 & 0.122 & 0.645 & 0.063 & 0.533 & 0.037 & 1.712 & 2.270 & 1.997 & 0.088 & 0.660 \\
\hline S- 14 & 3647 & 0.344 & 0.688 & 0.345 & 0.224 & 11.05 & 0.108 & 0.587 & 0.035 & 0.633 & 0.035 & 1.654 & 1.769 & 1.958 & 0.070 & 0.688 \\
\hline S- 15 & 3689 & 0.366 & 0.735 & 0.346 & 0.216 & 10.63 & 0.113 & 0.643 & 0.063 & 0.695 & 0.029 & 1.773 & 2.130 & 1.606 & 0.081 & 0.616 \\
\hline S- 16 & 3704 & 0.378 & 0.696 & 0.319 & 0.239 & 10.44 & 0.116 & 0.638 & 0.059 & 0.448 & 0.022 & 1.734 & 2.165 & 1.978 & 0.137 & 0.664 \\
\hline S- 17 & 3866 & 0.365 & 0.723 & 0.328 & 0.227 & 11.47 & 0.125 & 0.665 & 0.048 & 0.665 & 0.037 & 1.790 & 2.003 & 1.749 & 0.094 & 0.638 \\
\hline-18 & 3793 & 0.346 & 0.667 & 0.335 & 0.22 & 10.35 & 0.13 & 0.574 & 0.037 & 0.477 & 0.039 & 1.626 & 2.044 & 1.730 & 0.096 & 0.629 \\
\hline-19 & 3809 & 0.319 & 0.654 & 0.31 & 0.255 & 10.33 & 0.116 & 0.645 & 0.068 & 0.449 & 0.027 & 1.649 & 1.997 & 1.988 & 0.084 & 0.665 \\
\hline-20 & 3863 & 0.335 & 0.695 & 0.318 & 0.218 & 10.25 & 0.105 & 0.568 & 0.155 & 0.557 & 0.025 & 1.795 & 1.830 & 1.721 & 0.093 & 0.632 \\
\hline Mean & & 0.345 & 0.696 & 0.331 & 0.233 & 10.67 & 0.120 & 0.614 & 0.649 & 0.528 & 0.032 & 1.695 & 2.00 & 1.79 & 0.145 & 0.643 \\
\hline
\end{tabular}

kerogen which suggests over-maturation of pre-existing kerogen within the dry and wet gas domain.
$(2.21 \mathrm{wt} \%)$ the organic matter richness and hydrocarbon generative potential of the Nkporo Formation are excellent

Table 4 Summary of Rock-Eval pyrolysis analysis

\begin{tabular}{|c|c|c|c|c|c|c|c|c|c|c|}
\hline Unit & ID & $\begin{array}{l}\text { S1 } \\
\text { (mgHC/grock) }\end{array}$ & $\begin{array}{l}\text { S2 } \\
\text { (mgHC/grock) }\end{array}$ & $\begin{array}{l}\text { TOC } \\
(w t \%)\end{array}$ & $\begin{array}{l}\mathrm{GP} \\
(\mathrm{S} 1+\mathrm{S} 2)\end{array}$ & $\begin{array}{l}\text { S3 } \\
\text { (mgHC/grock) }\end{array}$ & $\begin{array}{l}\text { HI } \\
(\mathrm{mgHC} / \mathrm{gTOC})\end{array}$ & $\mathrm{OI}$ & PI & $\begin{array}{l}T_{\max } \\
\left({ }^{\circ} \mathrm{C}\right)\end{array}$ \\
\hline \multirow{9}{*}{$\begin{array}{l}\text { Upper } \\
\text { member }\end{array}$} & S-1 & 0.03 & 0.07 & 0.82 & 0.10 & 0.92 & 7.89 & 112.20 & 0.30 & 435 \\
\hline & S-2 & 0.02 & 0.05 & 0.57 & 0.07 & 0.70 & 6.78 & 121.95 & 0.29 & 425 \\
\hline & S-3 & 0.04 & 0.09 & 1.07 & 0.13 & 0.93 & 1.18 & 87.24 & 0.31 & 426 \\
\hline & S-4 & 0.02 & 0.06 & 0.66 & 0.08 & 0.17 & 8.71 & 25.91 & 0.25 & 426 \\
\hline & S-5 & 0.05 & 0.10 & 1.23 & 0.15 & 0.43 & 8.33 & 34.96 & 0.33 & 435 \\
\hline & S-6 & 0.07 & 0.14 & 1.72 & 0.21 & 0.27 & 7.01 & 15.68 & 0.33 & 445 \\
\hline & S-7 & 0.03 & 0.11 & 1.15 & 0.14 & 0.22 & 4.39 & 19.16 & 0.21 & 443 \\
\hline & S-8 & 0.03 & 0.10 & 1.07 & 0.13 & 0.29 & 4.97 & 27.20 & 0.23 & 437 \\
\hline & S-9 & 0.04 & 0.15 & 1.56 & 0.19 & 0.69 & 7.38 & 44.29 & 0.21 & 446 \\
\hline \multirow{9}{*}{$\begin{array}{l}\text { Lower } \\
\text { member }\end{array}$} & S-10 & 0.06 & 0.11 & 1.39 & 0.17 & 0.66 & 8.54 & 47.35 & 0.35 & 477 \\
\hline & S-11 & 0.08 & 0.1 & 1.48 & 0.18 & 0.95 & 8.71 & 64.36 & 0.44 & 478 \\
\hline & S-12 & 1.12 & 0.12 & 10.17 & 1.24 & 0.51 & 8.44 & 5.02 & 0.94 & 470 \\
\hline & S-13 & 0.1 & 0.25 & 2.87 & 0.35 & 0.73 & 9.15 & 25.44 & 0.29 & 475 \\
\hline & S-14 & 0.13 & 0.28 & 3.36 & 0.41 & 0.86 & 8.13 & 25.58 & 0.32 & 445 \\
\hline & S-15 & 0.17 & 0.23 & 3.28 & 0.40 & 0.93 & 8.13 & 28.35 & 0.43 & 442 \\
\hline & S-16 & 0.16 & 0.09 & 2.05 & 0.25 & 0.77 & 9.58 & 37.56 & 0.64 & 470 \\
\hline & S-17 & 0.16 & 0.11 & 2.21 & 0.27 & 0.9 & 9.38 & 40.65 & 0.59 & 478 \\
\hline & S-18 & 0.15 & 0.23 & 3.12 & 0.38 & 0.81 & 9.63 & 25.99 & 0.30 & 488 \\
\hline
\end{tabular}


because good source rocks are regarded to have a TOC value of more than $0.5 \%$ (Veld et al. 1993; Al-Selwi and Joshi 2015). The hydrogen index (HI) of organic matter has an average value of 7.57 but ranged from 1.18 to 9.63 whilst the oxygen index (OI) averages at 43.83 and ranged from 1.05 to 121.95 for all studied samples.

\section{Organic geochemical evaluation of carbonaceous shale}

The extracts of organic matters associated with the Nkporo shales revealed the concentration of $n$-alkanes and isoprenoid hydrocarbons from $n-\mathrm{C}_{12}$ to $n$ - $\mathrm{C}_{32}$ with a maximum peak at $n$ $\mathrm{C}_{17}$ (Fig. 6). The distribution of $n$-alkanes showed maximum unimodal peat at $n-\mathrm{C}_{17}$ with a moderate concentration of heavy $n$-alkanes (Fig. 6a). The result showed a substantial amount of pristane (Pr) and phytane (Ph (Fig. 6b) with a low concentration of the $\mathrm{Pr} / \mathrm{n}-\mathrm{C} 17$ and $\mathrm{P} / \mathrm{n}-\mathrm{C} 18$ from 5.27 to 6.98 and 1.75 to 1.97 respectively (Table 5). Based on the ratio of
$\mathrm{Pr} / \mathrm{Ph}$ value which ranged from 3.01 to 3.54 , the Nkporo shales are ascribed to a fluvio-marine and coastal swamp depositional environments since the ratio value is $>2.56$ under suboxic condition (Peters et al. 1999). Nevertheless, the plot of $\mathrm{Pr} / \mathrm{n}-\mathrm{C} 17$ against $\mathrm{Ph} / \mathrm{n}-\mathrm{C} 18$ suggests that the provenance of organic matter contained in the lower and upper Nkporo shale ensued from the terrigenous environment which is preserved under an anoxic condition (Fig. 7).

The concentrations of extractable organic matter (EOM) present in form of aromatic and aliphatic hydrocarbon are very low and this suggests that there is little or no bitumen extract from the studied shales (Table 5). The ratio of EOM to TOM of $1.87 \mathrm{~g} \mathrm{100/g}$ organic matter is lower than the sorption threshold of $2 \mathrm{~g} \mathrm{100/g}$ organic matter below which expulsion is considered to occur in source rocks. Furthermore, the high carbon preference indices (CPI) showed that the shale sediments can significantly generate and expel hydrocarbon since the CPI value is greater than 1 . It is likely the high contribution may have resulted from the tertiary post-deformational between

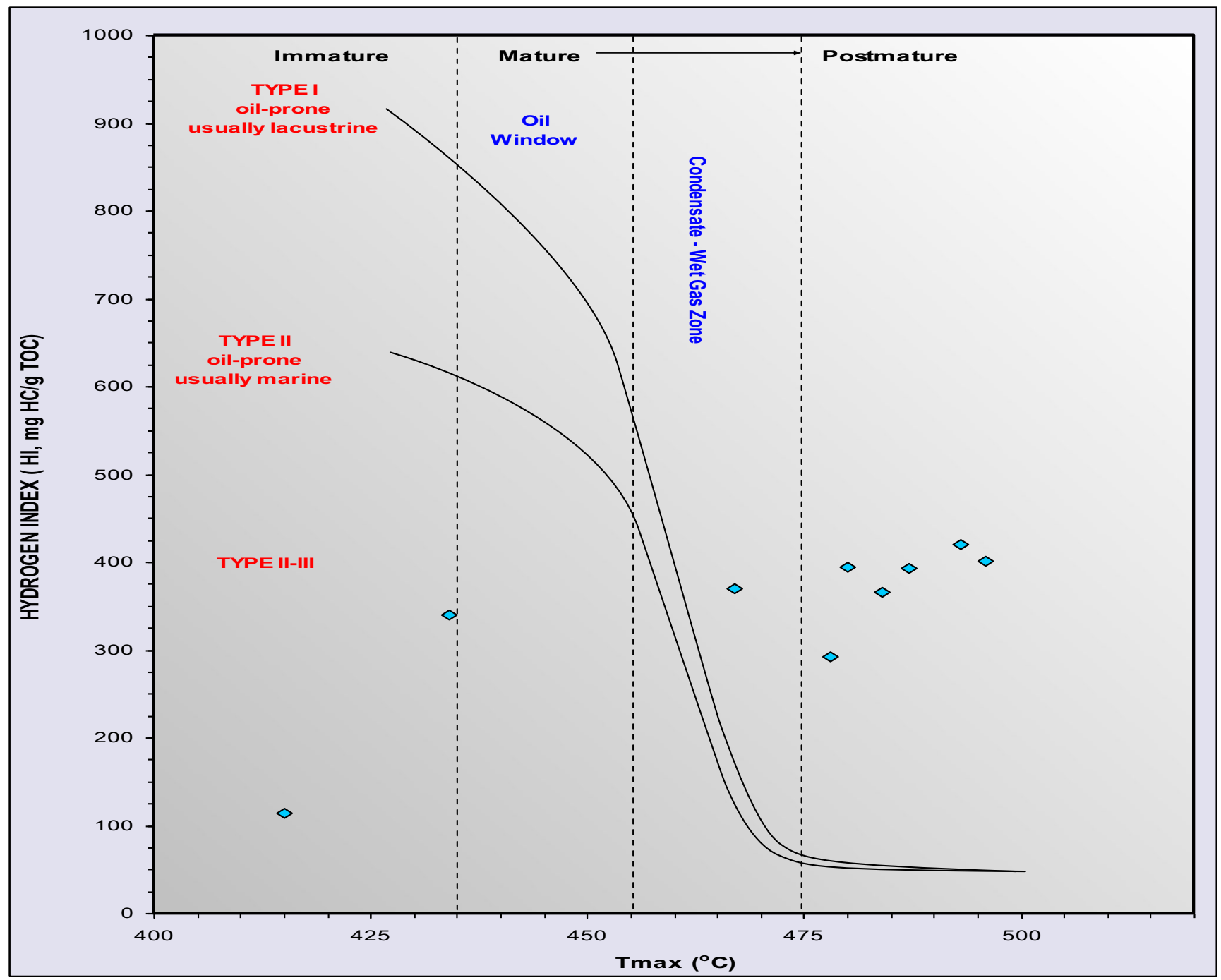

Fig. 4 Classification of kerogen of Nkporo shale on a HI vs T-max diagram for well 2 after (Hakimi et al. 2010) 

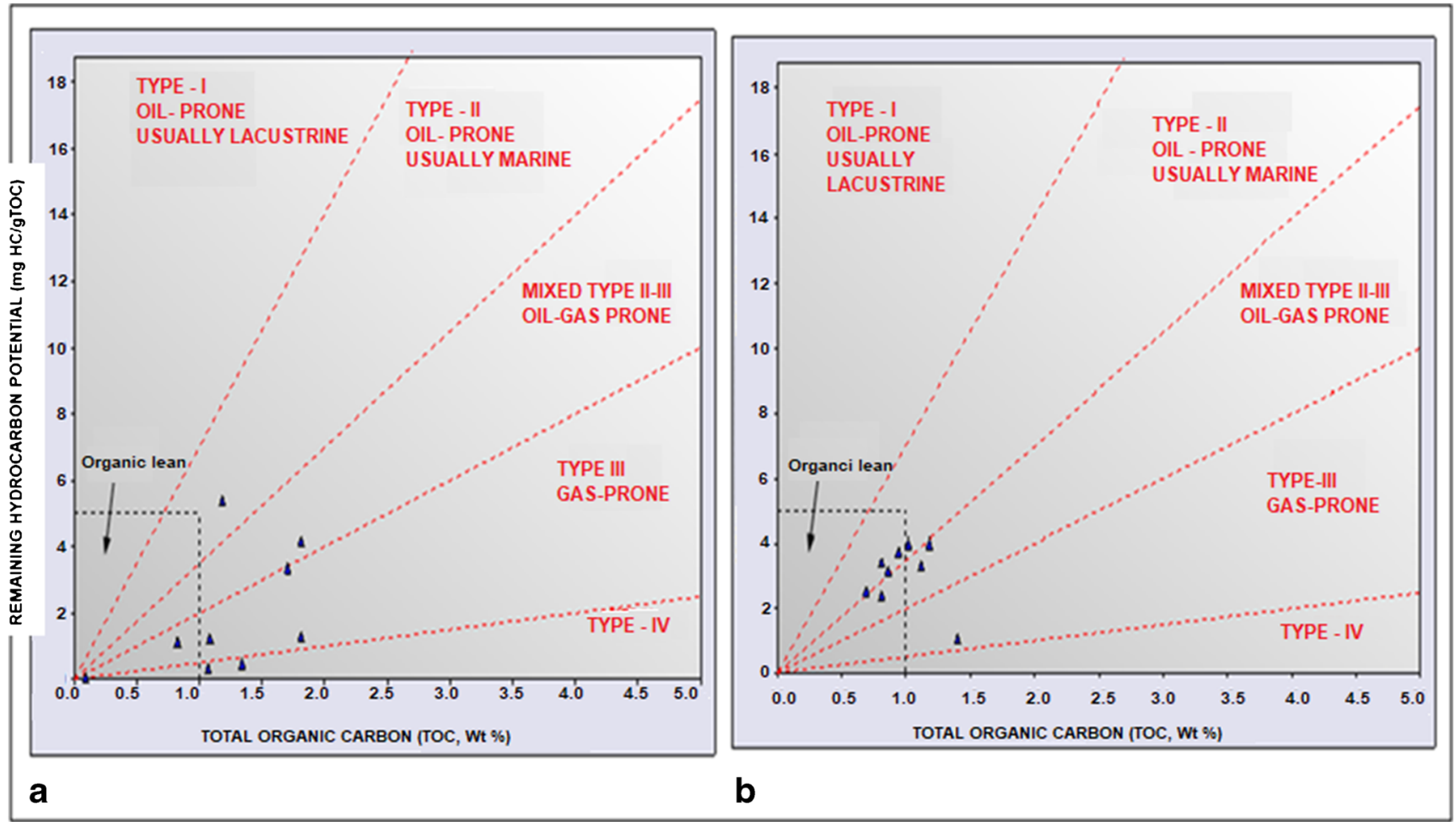

Fig. 5 a Classification of Kerogens of Nkporo shale on $\mathrm{S}_{2}\left(\mathrm{mgHC} / \mathrm{g}\right.$ rock) vs TOC (\%), well-1. b Classification of Kerogens of Nkporo shale on $\mathrm{S}_{2}$ (mgHC/g rock) vs TOC (\%), well-2 after (Hakimi et al. 2010)

the marginal southern marine Niger Delta Basin and the Cretaceous Benue Trough Basin (Whiteman 1982,Akande et al. 2012).

The Nkporo shale samples showed more of the $15 \alpha(\mathrm{H})$ and $18 \alpha(\mathrm{H})$ structural isomers, with a preponderance of $\mathrm{C}_{27}$ or $\mathrm{C}_{29}$ relative to $\mathrm{C}_{28}$ even/odd steranes and diasteranes $\left(\mathrm{C}_{27}-\mathrm{C}_{29}\right)$ and low abundances of short-chain pregnanes (Fig. 6b). The average ratio of $\mathrm{C}_{27}$ to $\mathrm{C}_{29}$ regular steranes is 0.95 , with an

Table 5 Biomarker analysis results of well 1 and well 2

\begin{tabular}{|c|c|c|}
\hline Organic geochemical parameters & Well 1 & Well 2 \\
\hline Pristane/phytane & 3.01 & 3.54 \\
\hline Pristane/n-17 & 5.27 & 6.98 \\
\hline Phytane/n-18 & 1.75 & 1.97 \\
\hline EOM (mg/g) & 0.92 & 6.71 \\
\hline CPI & 1.05 & 1.04 \\
\hline Rock wt. (g) & 8.90 & 7.89 \\
\hline Steranes- $\mathrm{C}_{27}(\%)$ & 28 & 29 \\
\hline Steranes- $\mathrm{C}_{28}(\%)$ & 26 & 30 \\
\hline Steranes- $\mathrm{C}_{29}(\%)$ & 30 & 30 \\
\hline Oleanane $(\%)$ & 0.72 & 0.97 \\
\hline Diasteranes index & 0.93 & 0.96 \\
\hline Gammacerane index & 0.51 & 0.74 \\
\hline $\mathrm{C}_{29} / \mathrm{C}_{30}$ Hopane & 0.42 & 0.48 \\
\hline
\end{tabular}

average concentration value of 0.92 and the moderate amount of $\mathrm{C}_{27}$ steranes with $\mathrm{C}_{30}$ hopane has been noted to receive organic matter input from marine sources (Wells 2014). Whilst the presence of regular steranes suggests terrestrial input, the $\mathrm{C}_{29}$ may be related to algae and marine diatoms. In comparison to the regular steranes, the presence of diasteranes indicates a source rock rich in clay minerals owing to the catalytic transformation of steroids to diasteranes (Wells 2014). The gammacerane index (gammacerane/ $\mathrm{C} 30 \alpha \beta$ hopane) values of the studied shale samples ranged from $0.51-0.74$ whilst the oleanane index (oleanane/ C $30 \alpha \beta$ hopane) values of these samples ranged from 0.72 0.97(Table 5). The presence of gammacerane (Fig. 6b) favours a depositional environment characterised with marine, lacustrine and deltaic settings and typify a high-salinity environment resulting from hypersalinity and suboxidation at depth. Significantly, a stratified water column in non-marine and marine setting can be identified using the gammacerane indicator. The gammacerane index suggests weakly reducing brackish condition whilst the presence of Oleanane in Cretaceous or younger sediments indicate the contribution of cell wall and woody plant tissues from the terrestrial higher plant which may mature to gas generating kerogen (Ekweozor and Telnaes 1990,Osuji and Antia 2005). The biomarker ratio indices of diasteranes, gammacerane and $\mathrm{C}_{29} / \mathrm{C}_{30}$ hopane showed concentration between 0.5 and 1.0 thus indicating moderately to highly matured source rock (Uzoegbu et al. 2013). 


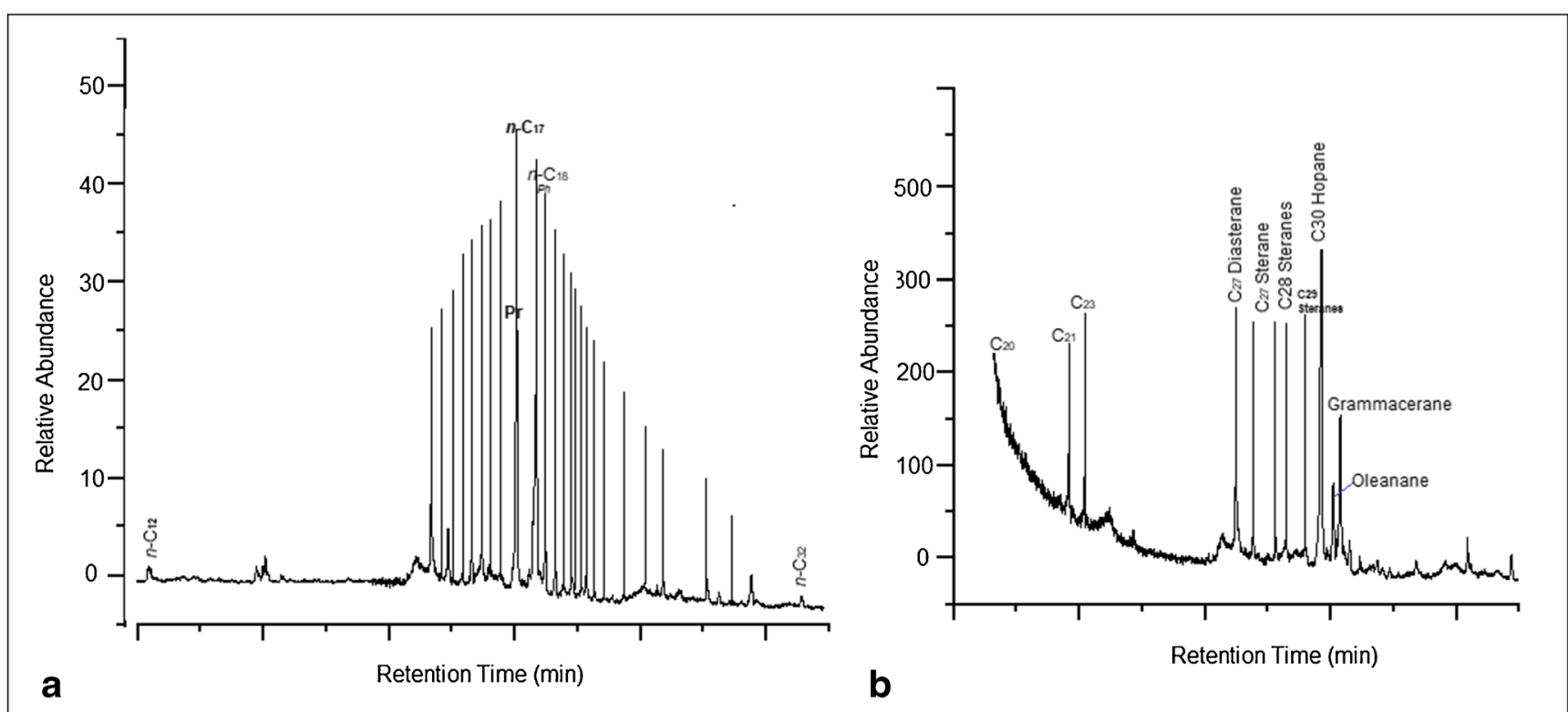

Fig. 6 Ion chromatogram for representative Nkporo shales, a $n$-alkanes and isoprenoid hydrocarbon-m/z 85 b saturated hydrocarbon $\mathrm{m} / \mathrm{z} 217$ after (Ogungbesan and Adedosu 2020)

CPI odd/ even carbon numbers; diasterane index: diasterane: $\mathrm{C}_{27} /$ steranes $\mathrm{C}_{29}$; gammacerane index: gammacerane/(gammacerane $+\mathrm{C}_{30}$ hopane), oleanane index (oleanane/C30 $\alpha$ hhopane)

\section{Organic maceral characterisation}

The organic maceral modal composition of the studied shale samples is presented in Table 6 . In both wells, vitrinite mainly dominates the organic macerals $(>50 \%)$ followed by liptinite and Inertinite. Given that vitrinite are macerals primarily derived from the lignin, cellulose and tannins of vascular plants particularly from the periderm (bark) and xylem (wood) tissues, the Npkoro Formation has the potential to predominantly generate natural gas. The relatively low average composition of liptinite macerals ( $\sim 9 \%)$ compared to vitrinite $(\sim 52 \%)$ and inertinite $(\sim 19 \%)$ suggests little or no generative potential for oil compared to gas. Liptinite is strong oil-prone whilst inertinite has negligible hydrocarbon generation potential but could generate gas as well.

\section{Conclusions}

The major oxide ratio indices revealed the biophile elements which are associated with cretaceous carbonaceous shale show a single-phase organic matter and low Fe content hence suggesting an overmatured sediment where intense reworking processes have taken place during fluvial transportation and deposition. The total organic carbon content concentration exceeds wet
Fig. 7 Source shale extracts of Pristane/n-C17 alkane ( $\mathrm{Pr} / \mathrm{n}-\mathrm{C} 17)$ against phytane/n-C18 alkane $(\mathrm{Ph} / \mathrm{n}-\mathrm{C} 18)$ after (Mißbach et al. 2016)

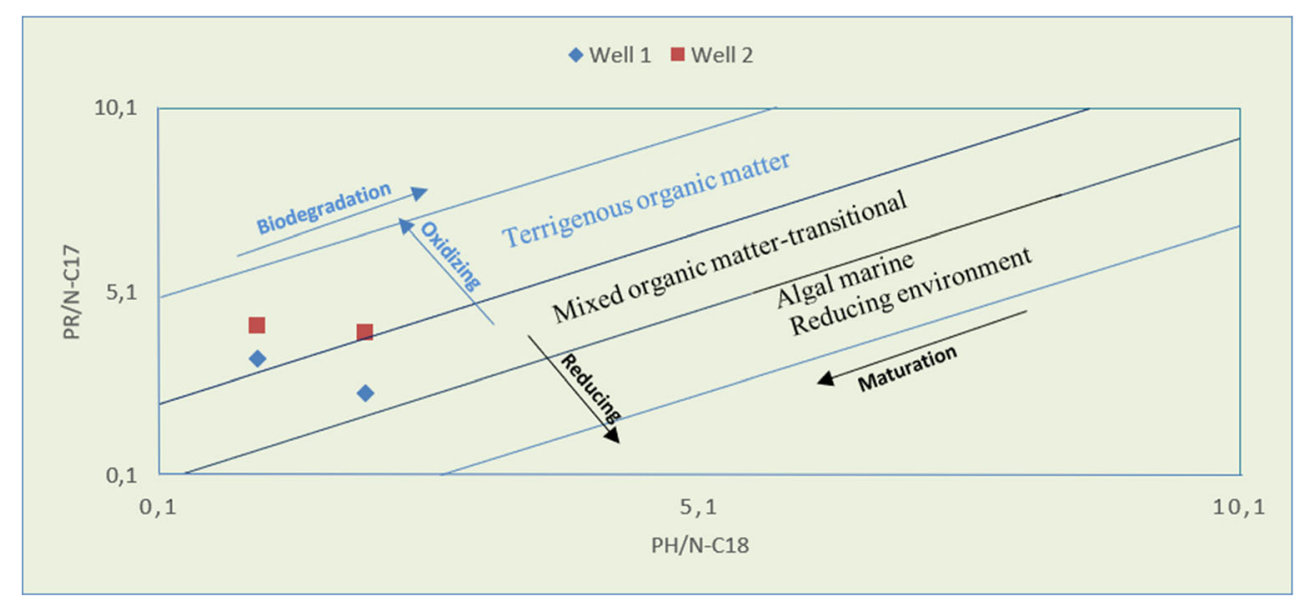


Table 6 Modal composition of organic macerals

\begin{tabular}{|c|c|c|c|c|c|c|c|}
\hline Well 1 & Depth (m) & Vitrinite $(\%)$ & Liptinite (\%) & Inertinite $(\%)$ & Mineral compd $(\%)$ & Pyrite $(\%)$ & Others $(\%)$ \\
\hline S-1 & 1522 & 57 & 15 & 9 & 11 & 8 & 3 \\
\hline S- 2 & 1575 & 34 & 28 & 10 & 23 & 5 & 2 \\
\hline S- 3 & 1640 & 48 & 15 & 12 & 18 & 7 & 2 \\
\hline S-4 & 1673 & 42 & 25 & 15 & 12 & 6 & 1 \\
\hline S-5 & 1680 & 40 & 32 & 10 & 12 & 6 & 3 \\
\hline S-6 & 1703 & 45 & 25 & 8 & 16 & 6 & 2 \\
\hline $\mathrm{S}-7$ & 1765 & 50 & 20 & 9 & 12 & 9 & 2 \\
\hline $\mathrm{S}-8$ & 1800 & 48 & 15 & 12 & 18 & 7 & 2 \\
\hline S-9 & 1900 & 53 & 18 & 9 & 12 & 8 & 3 \\
\hline Well 2 & Depth (m) & Vitrinite (\%) & Liptinite (\%) & Inertinite $(\%)$ & Mineral compd (\%) & Pyrite $(\%)$ & Others $(\%) \mathrm{S}$ \\
\hline S-10 & 3360 & 43 & 18 & 7 & 22 & 10 & 2 \\
\hline S-11 & 3474 & 50 & 20 & 10 & 14 & 7 & 3 \\
\hline S-12 & 3514 & 55 & 10 & 5 & 21 & 9 & 2 \\
\hline S-13 & 3543 & 40 & 32 & 10 & 12 & 6 & 4 \\
\hline S-14 & 3576 & 35 & 22 & 12 & 26 & 5 & 5 \\
\hline S-15 & 3619 & 38 & 29 & 5 & 19 & 9 & 2 \\
\hline S-16 & 3647 & 65 & 18 & 4 & 8 & 5 & 1 \\
\hline S-17 & 3680 & 30 & 25 & 15 & 25 & 12 & 1 \\
\hline S-18 & 3700 & 22 & 31 & 8 & 27 & 12 & 3 \\
\hline
\end{tabular}

and dry gas window threshold whilst its organic matter belongs to admixture of Type III and IV kerogen which indicate overmaturation of pre-existing kerogen within the dry and wet gas domain. The studied shale samples exhibited a thermal evolution of a Type III kerogen with initial HI between 650 and 800 mgHC/gTOC with a $T_{\max }$ value of $488^{\circ} \mathrm{C}$ and have a low hydrocarbon generation potential ranging from 0.07 to 0.15 . However, the average TOC content $(2.21 \mathrm{wt} \%)$ indicated a good source rocks for hydrocarbon since it exceeds threshold limit of $0.5 \%$. The plot of HI against $T_{\max }$ shows that the organic matter belongs to the Type-III kerogen which reflects the capability of the studied carbonaceous shale to generate more natural gas than oil particularly from the lower shale formation. The low concentrations of extractable organic matter (EOM) present in form of acyclic isoprenoid, aromatic and aliphatic hydrocarbon indicate little or no bitumen extract from the studied shale.

The presence of Oleanane in Cretaceous or younger sediments indicates the contribution of cell wall and woody plant tissues from the terrestrial higher plant which may mature to gas generating kerogen. The biomarker ratio indices of diasteranes, gammacerane and $\mathrm{C}_{29} / \mathrm{C}_{30}$ hopane showed concentration between 0.5 and 1.0 thus indicating moderately to highly matured source rock. Significantly, a stratified water column in nonmarine and marine settings can be identified using the gammacerane indicator whilst its index suggests weakly reducing brackish condition. The majority of organic macerals present in the formation is vitrinite which favours the generation of natural gas than oil. The high values of pristane/phytane ratio in both wells ( $>3$ ) and high carbon preference indices $(>1)$ indicate that the organic matter belongs to terrigenous source deposited under anoxic condition which is typical of non-marine shale formation. As such, the study reveals that the non-marine Npkoro Shale has significant potential to generate and expel natural gas apart from the current marine offshore basins.

\section{Declarations}

Conflict of interest The authors declared that there is no conflict of interests.

Open Access This article is licensed under a Creative Commons Attribution 4.0 International License, which permits use, sharing, adaptation, distribution and reproduction in any medium or format, as long as you give appropriate credit to the original author(s) and the source, provide a link to the Creative Commons licence, and indicate if changes were made. The images or other third party material in this article are included in the article's Creative Commons licence, unless indicated otherwise in a credit line to the material. If material is not included in the article's Creative Commons licence and your intended use is not permitted by statutory regulation or exceeds the permitted use, you will need to obtain permission directly from the copyright holder. To view a copy of this licence, visit http://creativecommons.org/licenses/by/4.0/.

\section{References}

Adebayo, Adegoke, Mustapha, Adeleye, Agbaji, Abidin (2018) Paleoenvironmental reconstruction and hydrocarbon potentials of 
upper cretaceous sediments in the anambra basin, southeastern nigeria. Int J Coal Geol 192:56-72

Akaegbobi IM, Nwachukwu JI, Schmitt M (2000) AAPG Memoir 73, Chapter 17: Aromatic hydrocarbon distribution and calculation of oil and gas volumes in post-santonian shale and coal, Anambra Basin, Nigeria

Akande, Egenhoff, Obaje, Ojo, Adekeye, Erdtmann (2012) Hydrocarbon potential of cretaceous sediments in the lower and middle benue trough, nigeria: Insights from new source rock facies evaluation. J Afr Earth Sci 64:34-47

Akande, Erdtmann (1998) Burial metamorphism (thermal maturation) in cretaceous sediments of the southern benue trough and anambra basin, nigeria. AAPG Bull 82:1191-1206

Akande, Lewan, Egenhoff, Adekeye, Ojo, Peterhansel (2015) Source rock potential of lignite and interbedded coaly shale of the ogwashi-asaba formation, anambra basin as determined by sequential hydrous pyrolysis. Int J Coal Geol 150:224-237

Akande, Ojo, Erdtmann, Hetenyi (2005) Paleoenvironments, organic petrology and rock-eval studies on source rock facies of the lower maastrichtian patti formation, southern bida basin, nigeria. J Afr Earth Sci 41:394-406

Akinlua, Adekola, Swakamisa, Fadipe \& Akinyemi 2010a. Source rock potential of selected cretaceous shale samples from orange basin south africa. Int Geol Rev., dol, 10.

Akinlua, Adekola, Swakamisa, Fadipe, Akinyemi (2010b) Trace element characterisation of cretaceous orange basin hydrocarbon source rocks. Appl Geochem 25:1587-1595

Akinlua, Olise, Akomolafe, Mccrindle (2016) Rare earth element geochemistry of petroleum source rocks from northwestern niger delta. Mar Pet Geol 77:409-417

Akinlua, Sigedle, Buthelezi, Fadipe (2015) Trace element geochemistry of crude oils and condensates from south african basins. Mar Pet Geol 59:286-293

Alberdi-Genolet, Tocco (1999) Trace metals and organic geochemistry of the machiques member (aptian-albian) and la luna formation (cenomanian-campanian), venezuela. Chem Geol 160:19-38

Al-Selwi, Joshi (2015) Source rock evaluation using total organic carbon (toc) and the loss-on-ignition (loi) techniques. Oil Gas Res 1:900 1000

Anakwuba, Ajaegwu, Ejeke, Onyekwelu, Chinwuko (2018) Sequence stratigraphic interpretation of parts of anambra basin, nigeria using geophysical well logs and biostratigraphic data. J Afr Earth Sci 139: 330-340

Baioumy, Salim, Arifin, Anuar, Musa (2018) Geochemical characteristics of the paleogene-neogene coals and black shales from malaysia: implications for their origin and hydrocarbon potential. J Nat Gas Sci Eng 51:73-88

Bassey, Eminue (2012) Petrographic and stratigraphic analyses of palaeogene ogwashi-asaba formation, anambra basin, nigeria. Nafta 63:247-254

Chen, Jiang, Liu, Jiang, Liu, Tan, Gao (2019) Mechanism of shale gas occurrence: Insights from comparative study on pore structures of marine and lacustrine shales. Mar Pet Geol 104:200-216

Cox, Lowe, Cullers (1995) The influence of sediment recycling and basement composition on evolution of mudrock chemistry in the southwestern united states. Geochim Cosmochim Acta 59:2919-2940

Edwards \& Santogrossi 1990. Divergent/passive margin basins: Aapg memoir 48. Tulsa: AAPG.

Ekweozor, Telnaes (1990) Oleanane parameter: verification by quantitative study of the biomarker occurrence in sediments of the niger delta. Org Geochem 16:401-413

Floyd, Shail, Leveridge, Franke (1991) Geochemistry and provenance of rhenohercynian synorogenic sandstones: implications for tectonic environment discrimination. Geol Soc, London, Spec Publ 57: 173-188

Geel, Schulz, Booth, Dewit, Horsfield (2013) Shale gas characteristics of Permian black shales in South Africa: results from recent drilling in the ecca group (eastern cape). Energy Procedia 40:256-265

Giwa, Adama, Akinyemi (2014) Baseline black carbon emissions for gas flaring in the niger delta region of nigeria. J Nat Gas Sci Eng 20: 373-379

Giwa, Nwaokocha, Kuye, Adama (2019) Gas flaring attendant impacts of criteria and particulate pollutants: a case of niger delta region of nigeria. J King Saud Univ-Eng Sci 31:209-217

Hakimi, Abdullah, Shalaby (2010) Source rock characterization and oil generating potential of the jurassic madbi formation, onshore east shabowah oilfields, republic of yemen. Org Geochem 41:513-521

Hayashi, Fujisawa, Holland, Ohmoto (1997) Geochemistry of 1.9 ga sedimentary rocks from northeastern Labrador, Canada. Geochim Cosmochim Acta 61:4115-4137

Ikhane PR, Adeagbo OA, Oyebolu OO, Oladipo OV (2019) An evaluation of a section of the campano-maastrichtian nkporo shale, anambra basin, south-eastern nigeria: Implications for provenance and palaeoenvironment of deposition. J Appl Geochem 21(2):258 268

Hofer, Wagreich, Neuhuber (2013) Geochemistry of fine-grained sediments of the upper cretaceous to paleogene gosau group (austria, slovakia): implications for paleoenvironmental and provenance studies. Geosc Front 4:449-468

Jegede, Adekola, Akinlua (2018) Trace element geochemistry of kerogens from the central niger delta. J Pet Explor Prod Technol 8:9991007

Kelman (2017) Linking disaster risk reduction, climate change, and the sustainable development goals. Dis Prev Manag: Int J 26:254-258

Lewan (1984) Factors controlling the proportionality of vanadium to nickel in crude oils. Geochim Cosmochim Acta 48:2231-2238

Mclennan, Nance, Taylor (1980) Rare earth element-thorium correlations in sedimentary rocks, and the composition of the continental crust. Geochim Cosmochim Acta 44:1833-1839

Mißbach, Duda, Lünsdorf, Schmidt, Thiel (2016) Testing the preservation of biomarkers during experimental maturation of an immature kerogen. Int J Astrobiol 15:165-175

Nolte, Geel, Amann-Hildenbrand, Krooss, Littke (2019) Petrophysical and geochemical characterization of potential unconventional gas shale reservoirs in the southern karoo basin, south africa. Int J Coal Geol 212:103249

Nwachukwu, Jeong, Pyrcz, Lake (2018) Fast evaluation of well placements in heterogeneous reservoir models using machine learning. J Pet Sci Eng 163:463-475

Obaje, Wehner, Scheeder, Abubakar, Jauro (2004) Hydrocarbon prospectivity of nigeria's inland basins: from the viewpoint of organic geochemistry and organic petrology. AAPG Bull 88:325-353

Ogala (2012) The geochemistry of lignite from the neogene ogwashiasaba formation, niger delta basin, southern nigeria. Earth Sci Res J 16:151-164

Ogala, Kalaitzidis, Christanis, Omo-Irabor, Akinmosin, Yusuf, Pasadakis, Constantinopoulos, Papaefthymiou (2019) Geochemical and organic petrological study of bituminous sediments from dahomey basin, sw nigeria. Mar Pet Geol 99:577-595

Ogungbesan, Adedosu (2020) Geochemical record for the depositional condition and petroleum potential of the late cretaceous mamu formation in the western flank of anambra basin, nigeria. Green Energy Environ 5:83-96

Ojijiagwo, Oduoza, Emekwuru (2018) Technological and economic evaluation of conversion of potential flare gas to electricity in nigeria. Procedia Manufact 17:444-451 
Okoyeh EI, Akpan AE, Egboka BCE, Okeke HI (2014) An assessment of the influences of surface and subsurface water level dynamics in the development of gullies in Anambra State, southeastern Nigeria. Earth Interact 18(4):1-24

Onuigbo EN, Etu-Efeotor JO, Okoro AU (2012) Palynology, paleoenvironment and sequence stratigraphy of the campanianmaastrichtian deposits in the anambra basin, Southeastern Nigeria. Eur J Sci Res 78(3):333-348

Osuji \& Antia 2005. Geochemical implication of some chemical fossils as indicators of petroleum source rocks.

Peters, Fraser, Amris, Rustanto, Hermanto (1999) Geochemistry of crude oils from eastern indonesia. AAPG Bull 83:1927-1942

Rui, Lu, Zhang, Guo, Ling, Zhang, Patil (2017) A quantitative oil and gas reservoir evaluation system for development. J Nat Gas Sci Eng 42: $31-39$

Sundararaman, Schoell, Littke, Baker, Leythaeuser, Rullkötter (1993) Depositional environment of toarcian shales from northern germany as monitored with porphyrins. Geochim Cosmochim Acta 57:42134218

Thomas, Partridge, Harthorn, Pidgeon (2017) Deliberating the perceived risks, benefits, and societal implications of shale gas and oil extraction by hydraulic fracturing in the us and uk. Nat Energy 2:1-7
Tissot (1984) Recent advances in petroleum geochemistry applied to hydrocarbon exploration. AAPG Bull 68:545-563

Unfcc 2015. Paris agreement. Fcccc/cp/2015/1. 9/rev. 1.

Uzoegbu, Obaje, Ekeleme (2013) Geochemical characterization and paleoenvironment of turonian dukul formation, ne nigeria. Sci Res J $1: 5-18$

Veld, Fermont, Jegers (1993) Organic petrological characterization of westphalian coals from the netherlands: Correlation between tmax, vitrinite reflectance and hydrogen index. Org Geochem 20:659-675

Wang, Liu, Bentley, Feng, Zhang (2018) Water use for shale gas extraction in the sichuan basin, china. J Environ Manag 226:13-21

Wells (2014) Biomarkers compounds as indicators of environments and maturation of source rocks of wells, north western desert, egypt. Mohamed m. El nady. Rev Lit 1

Whiteman 1982. Stratigraphy. Nigeria: Its petroleum geology, resources and potential. Springer.

Xi, Tang, Wang (2018) The reservoir characterization and shale gas potential of the niutitang formation: case study of the sy well in northwest hunan province, south china. J Pet Sci Eng 171:687-703 